\title{
A situational Analysis of the faculties' Industrial Attachment programme at public Technical Training Institutes (TTIs) in Bhutan
}

\author{
Sangay Tshewang
}

Technical Training Institute, Samthang, Wangdue Phodrang, Bhutan

Received: 15 Oct 2020; Received in revised form: 12 Jan 2021; Accepted: 03 Feb 2021; Available online: 13 Feb 2021 (C)2021 The Author(s). Published by The Shillonga Publication. This is an open access article under the CC BY license (https://creativecommons.org/licenses/by/4.0/).

\begin{abstract}
The study was conducted in three Technical Training Institutes (TTIs) in Bhutan. The objective of the study was to investigate the challenges facing industrial attachment as a learning experience for automobile faculties. The population of the study involved all the faculties of TTIs namely Ranjung, Thimphu and Samthang. However, the researcher used a sample size of 64 respondents (purposive sampling) for the study. The data was collected from the respondents through a research-designed survey questionnaire administered through the Online Google Form. Nonetheless, 58 questionnaires were received. The validity and reliability of the instruments were determined by pre-testing the instruments before taking into consideration for analysis. The data collected was analysed using SPSS software. Cronbach-Alpha analysis was used to determine the reliability value of data. And the value of pre-test data was calculated at 0.788 .

The findings of the study concluded that the faculties of the three automobile institutes expressed high satisfaction with the program objectives, the usefulness of the program, adequacy of knowledge and skills acquired through the program.

However, the study also concluded that the challenges they faced compromised the quality of engagement and meaningful learning experience. In this context, the researcher recommended that industrial attachment must be planned and implemented as a genuine learning experience right from the start. This could be done by allocating adequate funds to support the faculties' interns and, enable the Technical Vocational Education and Training (TVET) institution to maintain the relevancy of the attachment program and the industry. The immediate attachment supervisors of the industries should also be trained to deliver quality training and education to the faculties during the industrial attachment. This calls for a closer and synergized working relationship between the TVET institutions and the industries so that effective and uncompromised industrial attachment is ensured.
\end{abstract}

Keywords-challenges, faculty, industrial attachment, knowledge and skills, quality engagement.

\section{INTRODUCTION AND THE BACKGROUND}

The importance of Vocational Education and Training (VET) was recognized by Royal Government of Bhutan as early as second Five Year Plan (FYP) in the mid of 1960s. It was during the time that the first technical school, the Kharbandi Technical School was established in the country. A decade later, the Royal Government took a step further by restructuring and reviewing the courses of the school and shifting the focus more on the technical and vocational aspect of it. The nomenclature of the school was changed to Royal Technical Institute (RTI) under then the Ministry of Social Service. Further, the need for a national authority for technical education was conceived during 1974.

However, it was only in May 1999 that the Technical and Vocational Education Section (TVES) was disengaged from the Department of Education under then the Ministry of Health and Education (MoHE) to create the National 
Technical Training Authority (NTTA) through a Royal Charter. The NTTA was established to develop a vocational education and training system to - produce a skilled and productive workforce for the growing economy of the country.

The NTTA was responsible for the implementation of vocational education and training through the existing training institutions and different training schemes as well as regulating the quality of vocational education and training. In 2003, the functions of NTTA were transferred to the newly established Ministry of Labour and Human Resources (MoLHR). With this, roles and responsibilities of NTTA were bifurcated into two departments, the Department of Occupational Standards (DOS) and the Department of Human Resources (DHR) and later in 2017, it was renamed as Department of Technical Education (DTE). The DOS had the mandate to develop/support quality assurance system and vocational qualification framework and to develop/implement National Accreditation System (NAS) to accredit TVET programs with in the country, whereas DTE was mandated to ensure availability of adequate human resources both in terms of numbers and quality to facilitate sustainable socioeconomic development of the country. As such, DTE was entrusted with the responsibility for all aspects concerning TVET and skill development of the country.

While the MoLHR was committed to making TVET as the mainstream choice for school leavers and the youth, TVET in Bhutan encountered with packs of challenges. While there are more than 115 TVET (both public and private) providers in the country (MoLHR, 2020) the programs are limited to few skills areas due to lack of resources and know-how in diverse training areas. TVET also required higher investment and dynamism to match technological changes, industry needs, the rapid globalization of trade and commerce, sustainable development and emergence of the knowledge economy, thus requiring financial sustainability mechanism put in place.

Despite its long transformation, the TVET system is still constrained by the lack of relevancy of skills and training to actual labour market requirements, limited availability of qualified instructors, assessors, weak industry-institute linkages and a high unemployment rate of $2.1 \%$ (DEHD, 2016).

Although many variables affect the success of TVET programs, it is the nature of the interaction between trainer and trainees that has the greatest impact on the learning. The qualification of skilled workers is a key issue for the competitiveness of economics all over the world, and the quality of TVET trainers are crucial in determining the skills of future workers. Building the capacity of the TVET trainers is seen as one of the surest strategies to improve quality and delivery of TVET.

As such, the MoLHR since its inception has provided its professional and technical support to all the public and private TVET provides through the implementation of Training of Trainers (TOT) in pedagogy. Besides, the institute management also provided support in capacity development through industrial attachment program with industries to constantly update the technological changes. This initiative of trainers' industrial attachment did not seem to have improved since its implementation in early 2000 with no serious commitment from the stakeholders due to absence of national policy in place. The underline objective of updating knowledge and experience on changing technologies and acquire practical skills remain a distant dream which has a cascading effect on the quality of TVET graduates.

The above important issues have prompted the researcher to evaluate the industrial attachment programme offered by public TVET institutions. This study also aimed to investigate the challenges facing industrial attachment program.

\subsection{Statement of the problem}

Today's fast-moving, technology-driven world demands hands-on skills for survival in the employment market. Over the years, unemployment has become a major problem for the country and successive governments have not been able to solve it as expected despite putting in mechanisms to curve it. The findings from the tracer study (MoLHR, 2020) reported that the skills mismatch challenge is blamed for the contradictory problems of shortage of national skilled workforce and unemployment among the younger age cohort. It was also reported that many other cross-cutting factors appear to deter, demotivate or obstruct graduates from performing well in the labour market. To achieve this ambition, industrial training programmes for both the faculty and trainees were introduced in the TTIs since 2000 .

The purpose of attachment was to acquire practical skills in their occupational areas and to acquaint themselves with how new technologies, machines and equipment they have heard of and read about function. The essence of industrial attachment is to develop the practical competency of the trainer and provide them with the requisite knowledge to contribute their quota towards developing society and meet industrial standards after graduation.

Several concerns were being raised by employers on the TVET institutions failing to produce graduates with relevant 
skills for employment. This has become a problem worrying stakeholders including trainees and trainers because on the job training is done in the same industry or organizations. Many faculties on attachment blame on- the -job training environments. Thus, one of the most important features of technical and vocational education and training is its orientation towards the world of work and the inclusion of work-integrated learning (Donkor et al, 2009).

The unmet objectives of the faculty who undergoes industrial attachment program have been extensively expressed by the current trainers although they are sent yearly depending on the availability of budget. It was of their view that current practices of sending them to the attachment for two weeks need thorough scrutiny. They expressed that the learning outcome during attachment was 5\% if they are sent to private workshops and $30-40 \%$ if attached to government-owned workshops. They also pointed out that most of the time they are left alone without any care and responsibility by the proprietor and quite often, the attachment period is completed in doing irrelevant jobs.

Thus, attempt is being made to undertake a situational analysis on current practices of industrial attachment and recommend few strategies to the relevant agencies for effective industrial attachment for faculties.

\subsection{Purpose of the study}

The purpose of this study was to investigate whether automobile faculties' industrial attachment provides a meaningful and effective learning experiences to the faculties involved. The study hoped to achieve this by investigating the attainment of attachment objectives, adequacy of the skills gained, the usefulness of the program, challenges faced by the faculties during their industrial attachment and explore some strategies to curb the issues. Further, it was also to investigate the extent to which theory and practice in the curriculum relate.

\subsection{Research Objectives}

The general objective of this study was to investigate the challenges facing industrial attachment as a learning experience for automobile faculties. To accomplish this, the study was guided by the following specific objectives:

1. To determine the extent to which theory and practice relate as per the curriculum.

2. To identify the challenges faced by faculties while on industrial attachment.
3. To establish the synergy for effectiveness between the Institute and industry supervision during the industrial attachment.

4. To find out whether automobile faculties' industrial attachment provides a meaningful learning experience to the staff involved.

5. Determine strategies for effective implementation of an industrial attachment.

\subsection{Research question}

The research aimed to answer the following questions:

1. Do the current practices of attachment fulfil the objectives of the program?

2. How do faculties of automobile institutes rate the usefulness of the industrial attachment program?

3. How adequate are the knowledge and the skills acquired during attachment?

4. What are the problems experienced by students during their industrial attachment?

5. How are we going to make this industrial attachment program more effective and efficient? (Strategies)

\subsection{Significance of the study}

Industrial attachment is a fundamental and additional component of the TVET programmes offered in many technical institutions in Bhutan as a means to enhance capacity development of trainers besides TOT. The findings of this study were therefore expected to be a great use to technical education planners and policymakers by giving them a picture of the challenges faced by the institutes while implementing industrial attachment. The findings of this study would also assist TVET leaders in developing a new and innovative approach to staff industrial attachment involving all the stakeholders. This would call for a strong working relationship among faculties, the industry and the institutions offering the programme.

Apart from adding to the world of knowledge in TVET faculty industrial attachment, this study would also act as a provocation and a springboard from where other researchers can carry out further research in the field of industrial attachment. Although the programme was about three decades old it still has teething problems. There has still several issues to be attended to. Therefore, the need to get feedback from faculty on their perception of these industrial attachments plays a critical role in bringing a paradigm shift in the attachment process. 


\section{METHODOLOGY}

This section contains the methods and procedures that were employed in conducting the study. Here, the researcher gives a description of the Research design, Study variables, Target population, Sampling techniques and Sample size, Study instruments, Data collection techniques, Data analysis, scope of the study and its limitation, Reliability and Validity, and Ethical issues.

\subsection{Research Design}

The study employed cross-sectional descriptive survey with a researcher-designed questionnaire for data collection to provide answers to the research questions. Since the study sought to assess an on-going program, the survey research method was deemed appropriate. In the view of Osuala (1993), the survey method is appropriate for conducting a study into an on-going process. The choice of the survey method was also informed by the views of Cohen and Manion (1995) who have indicated that the survey approach was useful in comparing conditions of an on-going activity against pre-determined standards. The study tried to answer the questions of what, when, where and how but not on why.

\subsection{Research Instrument}

Although several instruments for data collection could have been used, the study employed the researcher designed survey questionnaire. Questions, both structured and open-ended were used to collect data from the faculties. The structured questions were used because they were easier to administer, analyse and economical in terms of time and money. Openended question included in the questionnaire helped to inspire the respondents to a greater depth of responses about their experiences during industrial attachment. The researcher used online google forms to distribute the survey questionnaire through their email.

\subsection{Sample size and location}

The target population were faculties of the three institutes that offer automobile course. Due to inconveniences in covering the whole population of the 6 TTIs and 2 Institute of Zorig Chusum (IZCs) and also to ensure credibility of the study, purposive sampling was used to determine number of samples from TTI Ranjung, TTI Thimphu and TTI Samthang. Those were faculties who had gone for industrial attachment during their service time at least for once. Of the 64 respondents from three automobile institutions whom I sent them the survey questionnaire through Google Form, 58 of them have responded the questionnaire achieving the minimum sample size requirement. However, the sample size was determined by using the formula developed by Krejcie \& Morgan (1970) which required minimum of 55 sample size. The equation is:

$$
\begin{aligned}
& \mathrm{s}=\mathrm{X}^{2} \mathrm{NP}(1-\mathrm{P}) \div \mathrm{d}^{2}(\mathrm{~N}-1)+\mathrm{X}^{2} \mathrm{P}(1-\mathrm{P}) \\
& s=\text { required sample size. } \\
& X^{2}=\text { the table value of chi-square for } 1 \text { degree of } \\
& \text { freedom at the desired confidence level }
\end{aligned}
$$

$$
\text { (3.841). }
$$

$N=$ the population size

$P=$ the population proportion (assume to be .50

since this would provide the maximum sample

size).

$d=$ the degree of accuracy expressed as a proportion (.05).

\subsection{Method of data analysis}

The data collected was edited and fact-checked for any inconsistencies. Pre-coding had already been done for the closed-ended questions by using 5 points Likert scale whereas theme coding for the open-ended questions was done after data collection. The coded data were then analysed thematically using the Statistical Package for Social Sciences (SPSS). Cronbach-Alpha test was used to establish the significance of the relationships between the variables. The confidence level was set at $0.05(95 \%)$ as recommended by Cronbach (1951) for most descriptive researches. Descriptive statistics such as percentages and mean were used to describe the data while tables and pie charts were used to illustrate the results as shown in the following topics.

\subsection{Scope of the study}

This situational analysis on faculties' industrial attachment programme may not fulfil the needs of every institution as other programmed based study does, but it will be useful to the following stakeholders:

1. Department of Technical Education, MoLHR may use this as feedback on the industrial attachment activity to provide technical and financial support to strengthen the program.

2. Serve as the retrospective evaluation and foundation to developing prospective strategies by TTIs and IZCs on similar activity.

3. The attachment partners (Industries), policymakers and national TVET stakeholders for policy intervention. 


\subsection{Limitations}

The study took into consideration of faculties (teaching and administrative staff) from three automobile trade owing to diverse nature of the courses offered in TTIs and IZCs. Notwithstanding, this study may not merit appropriate representation and generalization but may use the findings of this study by other institutes in exploring answers to the issues they encounter in regards to their attachment system.

While the research design employed in this study has its own advantages, it has also limitations which the design cannot escape. The limitation lies in the sample size, construction of questionnaire items and response rates. Specifically, the purposive sampling method used here was subject to researcher's own interest in determining the samples of the study. This would have impeded the collection of representative data from the population which undermined and compromised the objectivity of study. Moreover, the survey research is prone to researcher error, where assumptions are made about the sample that may not be accurate.

\section{LITERATURE REVIEW}

This study was based on the Royal Government's TVET policy documents, DTE publications, MoLHR survey reports and other noteworthy international TVET studies. The precedence of the TVET has been introduced and established during as early as Bhutan's Five Year Plans which was started in 1961. Even so, the literature shows that there is a notable absence of deeper research and analysis into the issues and development of the TVET sector in Bhutan. The existing literatures are few and far from relevancy to the current settings. However, they are illuminating for this study.
Though the provided information in the existing literatures are beyond the scope of the study, they were directly or indirectly relevant to the assumptions and interpretation of the results herein. Some of the notable reference documents, as aforementioned, are the Human Resource Development Master plan for economic Sectors, TVET statistics, Tracer Study Report, National HRD Advisory and the TVET Blueprint. Further, in absence of existing literature in the Bhutanese context, the problem of the study was generated from those staff who had been in the system for decades and were victims of frequent transaction in the system.

\section{DATA PRESENTATION AND ANALYSIS}

This section deals with data collection and processing in which the Google Form was used to reduce the volume and process into significant information. Patton (1990) said, "the challenges is to make sense out of the massive amount of data, reduce the volume of information, identify significant patterns and construct a framework for communicating the essence of what the data reveal" (p.272). This section covered the biographical information of the participants such as gender, qualification, status and the number of years in the service.

\subsection{Gender}

Table 1 reveals the demographic information of respondents in which majority were $(67.2 \%)$ male and the remaining $32.8 \%$ were female. This indicated that male gender dominates the faculties in TVET institutions. Correspondingly, a similar trend was also reported in a TVET Statistic of Bhutan (2020) that over 70\% of 185 TVET regular staff were males, indicating the requirement for policy intervention to increase the number of female trainers to promote gender equity.

Table 1: Personal Information - Gender

Personal information - gender

\begin{tabular}{|ll|c|c|c|c|}
\hline & Frequency & Percent & Valid Percent & Cumulative Percent \\
\hline Valid & Male & 39 & 67.2 & 67.2 & 67.2 \\
& Female & 19 & 32.8 & 32.8 & 100.0 \\
& Total & 58 & 100.0 & 100.0 & \\
& \multicolumn{3}{|c}{} \\
\hline
\end{tabular}

\subsection{Employment status}

The employment status of the participants as well-indicated that most of the respondents $(82.8 \%)$ were trainers while the minority of $10.3 \%$ and $6.9 \%$ were management and administrative staff, respectively, that composites the faculties in the institute, as shown in table 2. 
Table 2: Personal Information - Employment Status

Personal information - Employment Status

\begin{tabular}{|ll|c|c|c|c|}
\hline & Frequency & Percent & Valid Percent & Cumulative Percent \\
\hline Valid & Trainer & 48 & 82.8 & 82.8 & 82.8 \\
& Management & 6 & 10.3 & 10.3 & 93.1 \\
& Others & 6.9 & 6.9 & 100.0 \\
Total & 58 & 100.0 & 100.0 & \\
\hline
\end{tabular}

\subsection{Qualification}

As presented in table 3, the data shows that $60.3 \%$ of the participants possessed diploma - the minimum qualification required to teach $\mathrm{NC}$ level as per the Bhutan Vocational Qualification Framework (BVQF) and less than 19\% had bachelor's degree. The $5.2 \%$ with a master degree were those in the management category as reported in A TVET Statistics of Bhutan, 2020. A similar stance was reported that out of 185 TVET trainers recorded in 2019, $66.5 \%$ of them were with diplomas and $24.3 \%$ had a bachelor's degree.

Table 3: Personal Information - Qualification

Personal information - qualification

\begin{tabular}{|cc|c|c|c|c|}
\hline & Frequency & Percent & Valid Percent & Cumulative Percent \\
\hline Valid & Master & 3 & 5.2 & 5.2 & 5.2 \\
& Degree & 11 & 19.0 & 19.0 & 24.1 \\
& Diploma & 35 & 60.3 & 60.3 & 84.5 \\
certificate & 9 & 15.5 & 15.5 & 100.0 \\
Total & 58 & 100.0 & 100.0 & \\
\hline
\end{tabular}

\subsection{No. of years in the service}

The table below (Table 4) revealed an experience of staff either in TVET or in the civil service in which $43.1 \%$ fall within $0-5$ years in the service, $8.6 \%$ in $6-10,25.9 \%$ in $11-15$ and $22.4 \%$ fell within 16 years above. It is of the view that more the number of years in the service more experienced he or she become with corresponding frequency of industrial attachment opportunity availed. We can infer that lesser the number of years in the service, lesser experienced a staff is in delivery of the program which reaffirmed that the experience gained is directly proportional to the number of industrial attachment programme availed by a staff. 
Table 4: Personal Information - No. of years in the service

Personal information- No. of years in service

\begin{tabular}{|c|c|c|c|c|c|}
\hline & & Frequency & Percent & Valid Percent & $\begin{array}{c}\text { Cumulative } \\
\text { Percent }\end{array}$ \\
\hline \multirow[t]{5}{*}{ Valid } & $0-5$ years & 25 & 43.1 & 43.1 & 43.1 \\
\hline & $6-10$ years & 5 & 8.6 & 8.6 & 51.7 \\
\hline & $11-15$ years & 15 & 25.9 & 25.9 & 77.6 \\
\hline & 16 and above & 13 & 22.4 & 22.4 & 100.0 \\
\hline & Total & 58 & 100.0 & 100.0 & \\
\hline
\end{tabular}

\subsection{Questions analysis}

The five points Likert Scale was considered with an interval scale of 1 to 1.8 strongly disagree, 1.81 to 2.60 disagree, 2.61 to 3.40 neutral, 2.41 to 4.20 agree and 4.21 to 5 strongly agree.

The resultant mean rating for each item was also computed. Thereafter, the computed mean ratings were compared with the theoretical mean rating (assuming a normal distribution of responses) of 2.50 to determine the attainment of the aspect of the program objective, the usefulness of the program, adequacy of skills acquired, organizational issues, challenges of the program and the strategies for improvement aspect of the program depicted by the questionnaire item.

A similar value had been considered for the other sections. As such the research findings are presented into six sections according to the six research questions posed above.

4.5.1 Research Question Do the current practices of attachment fulfil the objectives of the program?

The mean rating of each items in a section and the corresponding resultant mean rating was computed. The computed means were then compared with the theoretical mean rating (assuming a normal distribution of responses) of 2.50 to determine whether the objectives had been achieved or not. All the six items relating to the attainment of the program objectives had mean ratings and resultant mean ratings that far exceeded the theoretical mean (Table 5).

As indicated in table 5, the program objective of developing a positive attitude towards work had the highest resultant mean rating of 4.28. The lowest resultant mean rating of 3.78 was for the faculty to apply and sharpen old manipulative skills already acquired in their area of study. The results of the study suggest faculties of the automobile institution rated highly elements of the program objectives indicating satisfactory attainment of the program objectives. Thus, all three stakeholders felt that the program had achieved its set objectives. The findings are similar to those of Aleisa and Alabdulahfez (2002) who found that the cooperative education (attachment program) at Riyadh College of Technology had achieved its aims. In the present study, the objective nurture linkages with industry for trainee's industrial attachment programme (ATP) appears to have been attained. Similarly, Aleisa et al (2002) reported that the program at Riyadh College of Technology-enabled students to acquire a positive attitude towards work. They also found that the program provided students with the needed workplace skills similar to the findings of the present study.

The reported attainment of the objective of acquiring new manipulative practical skills during the industrial attachment was in agreement with the observation of Ryan and Imel (1996) that industrial attachment was one of the useful methods of imparting knowledge to students. This finding could be attributed to the fact that the attachment program afforded faculty the unique opportunity to engage in practical work of six hours a day on a five-day week basis on some specialized equipment and machinery which are not available in their institute's workshops. The above findings compared favorably with the finding of the present study that industrial attachment enabled faculty on attachment to apply and sharpen old manipulative skills already acquired in their areas of study. The objective of getting faculty acquainted with how new technologies, machines and equipment function also appears to have been attained. Schools and individuals find it very difficult to get specialized equipment to run quality education programs (Finch et al., 1999). It is in this light that 
the attainment of the objective of getting automobile faculties acquainted with new technologies is very refreshing.

The finding that faculties had an opportunity to apply theories and principles learnt in their areas of study is supported by Matamande \& et al (2012), Further, in the evaluation of a cooperative education program for science students at
Southern Cross University, Cullen (2005) established that students were able to use skills learned or acquired from their study, similar to the present findings. Furco (1996) also observed that industrial attachment provides "learning opportunities beyond the classroom walls" (p. 9) and that it enables students to see, feel and work with tools and machines to give practical meaning to what they have learnt in theory.

Table 5: Attainment of programme objectives

\begin{tabular}{|c|c|c|c|c|c|}
\hline \multicolumn{6}{|c|}{ Descriptive statistics } \\
\hline Statement & $\mathbf{N}$ & Minimum & Maximum & Mean & $\begin{array}{l}\text { Std. } \\
\text { Deviation }\end{array}$ \\
\hline $\begin{array}{l}\text { 1. Acquisition of new manipulative practical } \\
\text { skills during the industrial attachment period. }\end{array}$ & 58 & 1 & 5 & 3.93 & .792 \\
\hline $\begin{array}{l}\text { 2. Nurture linkages with industry for trainee's } \\
\text { industrial attachment (ATP). }\end{array}$ & 58 & 2 & 5 & 4.19 & .661 \\
\hline $\begin{array}{l}\text { 3. The program enables faculty to apply and } \\
\text { sharpen old manipulative skills already } \\
\text { acquired in their area of study. }\end{array}$ & 58 & 0 & 5 & 3.78 & .859 \\
\hline $\begin{array}{l}\text { 4. Acquaintance of how new technologies, } \\
\text { machine and equipment heard of and read } \\
\text { about in curriculum function. }\end{array}$ & 58 & 2 & 5 & 3.83 & .729 \\
\hline $\begin{array}{l}\text { 5. Acquire interpersonal skills that promote } \\
\text { personal growth and development. }\end{array}$ & 58 & 0 & 5 & 3.97 & .973 \\
\hline 6. Develop positive attitude towards work. & 58 & 3 & 5 & 4.28 & .615 \\
\hline Valid N (list wise) & 58 & & & & \\
\hline
\end{tabular}

4.5.2 Question: How do the faculties of automobile institutes rate the usefulness of the industrial attachment program?

The results which appeared in Table 6 indicated that all the six items relating to the usefulness of the program had mean ratings that far exceeded the theoretical mean. As indicated in Table 9, the 'opportunity to interact and share experiences and problems with industry staff' had the highest resultant mean rating of 4.12. The lowest resultant mean rating of 3.19 related to the 'attachment is a sort of break with financial incentives for staff'. The results of the study thus showed that faculties rated highly elements of the usefulness of the program.

The results of the study are consistent with the findings of Bailey and Merritt (1997) who reported that industrial attachment increases the learning power of students by enabling them to get job experiences and reinforce academic instruction through the use of applied learning opportunities. The finding that students had the opportunity to apply theories and principles learnt in their areas of study is supported by Cullen (2005).

Further, the result of the study also supports the findings of Cort \& et al., (2004) that industrial attachments allow trainees/faculties to update their skills and knowledge in their trades, exposes them to new methods and materials, gives them a realistic and holistic impression of their trades and brings elements of realism into their training. 
Table 6: Usefulness of the Industrial attachment

\begin{tabular}{|c|c|c|c|c|c|}
\hline \multicolumn{6}{|c|}{ Descriptive statistics } \\
\hline Statement & $\mathbf{N}$ & Minimum & Maximum & Mean & $\begin{array}{l}\text { Std. } \\
\text { Deviation }\end{array}$ \\
\hline $\begin{array}{l}\text { 1. Opportunity to apply theories and principles learnt in } \\
\text { one's area of study at the institute }\end{array}$ & 58 & 2 & 5 & 4.02 & .577 \\
\hline $\begin{array}{l}\text { 2. Opportunity to understand many things learnt in abstract } \\
\text { in one's area of study at the institute }\end{array}$ & 58 & 0 & 5 & 3.97 & .700 \\
\hline $\begin{array}{l}\text { 3. Opportunity to interact and share experiences and } \\
\text { problems with industry staff. }\end{array}$ & 58 & 2 & 5 & 4.12 & .727 \\
\hline $\begin{array}{l}\text { 4. Opportunity to know the contribution of industry to } \\
\text { national development. }\end{array}$ & 58 & 2 & 5 & 3.90 & .693 \\
\hline $\begin{array}{l}\text { 5. Obtain new learning experience related to trade and } \\
\text { beyond. }\end{array}$ & 58 & 2 & 5 & 4.09 & .571 \\
\hline $\begin{array}{l}\text { 6. Attachment is a sort of break with financial incentives for } \\
\text { staff. }\end{array}$ & 58 & 0 & 5 & 3.19 & 1.162 \\
\hline Valid N (list wise) & 58 & & & & \\
\hline
\end{tabular}

4.5.3 Question: How adequate is the knowledge and the skills acquired during an attachment?

The results which appeared in table 7 indicated that all the items concerning the adequacy of the knowledge and skills acquired during an attachment exceeded the normal distribution mean (2.50) agreeing all the statements.

As indicated in Table 7, 'the current practices of attachment modality should be continued' had the highest rating of 3.84 and the lowest rating of 2.93 was against the two weeks' attachment program is adequate. Although, the mean rating for the adequacy of two weeks' attachment was slightly higher than the normal distribution indicating that the period for the attachment was not adequate for many of the faculty members. The duration of the attachment for faculties differs from institute to institute ranging from two to three weeks depending upon the availability of budget and the time of individual faculty. Considering the above challenges, most of the faculties were sent on attachment for two weeks which they found very short as reflected in the table.
The duration of attachment being very less was supported by open-ended question responses asked in the questionnaire. Most of the respondents suggested that the duration of the attachment may increase to three to four weeks instead of two to acquire more skills in related trade. The winter and summer vacations could be the option for meaningful attachment. To strengthen this program in TTIs and IZCs this study revealed that there should be HRD master plan which covers duration for IAP, Institute - Industry roles and monitoring and evaluation. The absence of such a policy undermines the institute level professional development activity such as industrial attachment as there are no standard norms. A similar finding was also reflected in TVET Blueprint (2016) which acknowledged that a HRD master plan for the TVET sector will be developed to determine initial training of instructors entering the profession, and professional development to those already in the profession. 
Table 7: Adequacy of the knowledge and skills acquired

\begin{tabular}{|c|c|c|c|c|c|}
\hline \multicolumn{6}{|c|}{ Descriptive statistics } \\
\hline Statement & $\mathrm{N}$ & Minimum & Maximum & Mean & $\begin{array}{l}\text { Std. } \\
\text { Deviation }\end{array}$ \\
\hline $\begin{array}{l}\text { E.1: Workplace supervisors are the right people to assess } \\
\text { faculty on the attachment program }\end{array}$ & 58 & 1 & 5 & 3.78 & .773 \\
\hline $\begin{array}{l}\text { E.2: The competencies on which faculty on attachment are } \\
\text { assessed on the program are appropriate. }\end{array}$ & 58 & 2 & 5 & 3.62 & .721 \\
\hline E.3: The two weeks' attachment program is adequate. & 58 & 1 & 5 & 2.93 & 1.183 \\
\hline $\begin{array}{l}\text { E.4: There is adequate monitoring by the management } \\
\text { during attachment. }\end{array}$ & 58 & 0 & 5 & 3.22 & 1.140 \\
\hline $\begin{array}{l}\text { E.5: The current practices of attachment modality should be } \\
\text { continued. }\end{array}$ & 58 & 1 & 5 & 3.84 & .988 \\
\hline $\begin{array}{l}\text { E.6: The management addressed the issue during } \\
\text { attachment instantly. }\end{array}$ & 58 & 2 & 5 & 3.59 & .750 \\
\hline $\begin{array}{l}\text { E.7: The management provide equal opportunities } \\
\text { irrespective of the trades and position. }\end{array}$ & 58 & 1 & 5 & 3.81 & .868 \\
\hline Valid N (list wise) & 58 & & & & \\
\hline
\end{tabular}

4.5.4 Question: What challenges do faculty face during industrial attachment?

The industrial attachment programme with its benefits highlighted above had also challenges which cannot be left out for effective assessment concerning the area under study. Thus, the mean rating of each of the six items that answered the challenges of industrial attachment and the corresponding resultant mean rating was computed. The computed means were then compared with the theoretical mean rating (assuming a normal distribution of responses) of 2.50 to determine the challenges of the program. The results which appeared in table 8 indicated that all the six items relating to the challenges about the program had mean ratings that far exceeded the theoretical mean. As indicated in Table 8, 'attachments were made to relevant industries and workshops' had the highest resultant mean rating of 3.90. The results of the study thus showed that faculties rated highly elements of the challenges of the program listed in the table.

The mean rating of the statement 'faculty on attachment do not have free access to machines and equipment' was 3.34 rated highly on agreement indicated that faculties on attachment were not given free access to new equipment to work on. The issue of faculties not having free access to machines and equipment to work with justifies the assertion of Olugbenga (2009), who argued that for effective training to take place and to create skills that were relevant to the future during industrial attachment, institutions of training must update technology. However, the TTIs lacked this and with the technological environment changing constantly making it difficult for institutions of higher learning to keep abreast with the changes. This was further supported by the findings of MoLHR (2020) that graduates had rated the quality of training tools and equipment need some improvement. However, the shortage of fund to update tools and equipment in consonance with changing technology had remained a major challenge.

It also revealed by the data that technicians and the supervisors of the workshops/industries were suspicious of the knowledge and skills of our staff making them do work not related to their field of study. A similar case was also reported in African countries that students end up doing menial jobs and never do the essentials of the job as indicated by Dodge and McKeough (2003). 
Table 8: Challenges of the Attachment Programme

\begin{tabular}{|l|c|c|c|c|c|}
\hline \multicolumn{9}{|c|}{ Descriptive statistics } \\
\hline Statement & N & Minimum & Maximum & Mean & $\begin{array}{l}\text { Std. } \\
\text { Deviation }\end{array}$ \\
\hline $\begin{array}{l}\text { F.1: Faculty on attachment do not have free access to } \\
\text { machines and equipment to work with. }\end{array}$ & 58 & 1 & 5 & 3.34 & .965 \\
\hline $\begin{array}{l}\text { F.2: Faculty on attachment spends a lot of time in finding } \\
\text { attachment placement. }\end{array}$ & 58 & 0 & 5 & 3.00 & 1.076 \\
\hline $\begin{array}{l}\text { F.3: Firms/industries are suspicious of the faculty's prior } \\
\text { knowledge. }\end{array}$ & 58 & 0 & 5 & 3.10 & 1.021 \\
\hline $\begin{array}{l}\text { F.4: Faculty are exposed to appropriate skills, task and } \\
\text { jobs relating to their profession during attachment. }\end{array}$ & 58 & 1 & 5 & 3.78 & .773 \\
\hline $\begin{array}{l}\text { F.5: Attachments were made to relevant industries and } \\
\text { workshops. }\end{array}$ & 58 & 0 & 5 & 3.90 & .986 \\
\hline $\begin{array}{l}\text { F.6: Lack of financial support affects the program } \\
\text { implementation. }\end{array}$ & 58 & 0 & 5 & 3.53 & 1.112 \\
\hline Valid N (list wise) & 58 & & & & \\
\hline
\end{tabular}

4.5.5 Question: How are we going to make this industrial attachment program more effective and efficient? (Strategies)

Findings from table 9 disclosed that the faculties agreed with all the eight strategies that were proposed to improve the effectiveness of the industrial attachment programme with the highest mean rating of 4.19 and the lowest rating of 3.71. Creation of strong linkages with industries is also viewed as a key strategy. Meyer (2008) viewed lack of linkages resulting in individual approaches leading to a lack of adequate funding, knowledge and basic resources for IAP enhancement. Creation of strong linkages will promote the participation of faculties, institutions, host organisations and other stakeholders in a more meaningful and relevant manner. This helps to develop a sense of belonging for a common purpose in managing the IAP for automobile institutions in Bhutan.

Meanwhile, the results also indicated that there should be early supervision from the management while workplace supervisors were encouraged to make the supervision constantly to achieve the objectives as supported by Baechle and Earle (2008) who argued that effective attachment will only be achieved if there is systemic and constant monitoring of the program form all the stakeholders. Frequent supervision visits to faculty on attachment by the training institutions were indicated to improve the industrial attachment programme in many countries. This indicated that they are part and parcel in getting instant feedback (Donkor et al., 2009).

Likewise, industrial attachment is an indispensable component of developing faculties' competences in their areas of specialization and the process can only achieve desired results if they were placed under the supervision of experienced and seasoned personnel (Arikewuyo, 1999). The data also indicated the need for trained and competent mentors and assessors with a mean rating of 3.83. Training of counterpart (mentors) will allow identification of improvements needed and feedback to the system. Mentors and assessors, therefore, need training and support in how to use assessment tools and mentoring strategies to promote meaningful learning through industrial attachment. This will leave each part benefiting accordingly in the system, mentors receiving the respect they deserve commanded by their effectiveness in executing their mentorship role.

From the responses in Table 9, one could therefore conclude that if the stated strategies are vigorously pursued, there is no doubt that the industrial training programme would be effective and produce the expected faculties who may be capable of theorizing practice and putting theory into practice to develop expert knowledge. 
Table 9: Strategies for improvement

\begin{tabular}{|c|c|c|c|c|c|}
\hline \multicolumn{6}{|c|}{ Descriptive statistics } \\
\hline Statement & $\mathrm{N}$ & Minimum & Maximum & Mean & $\begin{array}{l}\text { Std. } \\
\text { Deviation }\end{array}$ \\
\hline G.1: Improve the linkages between institute and industries & 58 & 3 & 5 & 4.19 & .606 \\
\hline $\begin{array}{l}\text { G.2: There should be an early follow-up so that supervisor } \\
\text { can make their input. }\end{array}$ & 58 & 2 & 5 & 4.07 & .617 \\
\hline $\begin{array}{l}\text { G.3: Frequent supervision from workplace supervisors } \\
\text { should be introduced. }\end{array}$ & 58 & 1 & 5 & 3.71 & .955 \\
\hline $\begin{array}{l}\text { G.4: Feedback from the industries/firms should be } \\
\text { discussed with faculty. }\end{array}$ & 58 & 2 & 5 & 4.16 & .616 \\
\hline $\begin{array}{l}\text { G.5: There should be post attachment seminar for faculty } \\
\text { and supervisors. }\end{array}$ & 58 & 1 & 5 & 3.86 & .888 \\
\hline $\begin{array}{l}\text { G.6: Workplace supervisors should be trained on how to } \\
\text { assess faculty on attachment. }\end{array}$ & 58 & 2 & 5 & 3.83 & .798 \\
\hline $\begin{array}{l}\text { G.7: There should be a workshop for all stakeholders } \\
\text { involved in the programme to reach a common consensus. }\end{array}$ & 58 & 2 & 5 & 3.71 & .726 \\
\hline $\begin{array}{l}\text { G. } 8 \text { : A robust monitoring mechanism should be instituted } \\
\text { by both the parties. }\end{array}$ & 58 & 0 & 5 & 3.71 & .937 \\
\hline Valid N (listwise) & 58 & & & & \\
\hline
\end{tabular}

\section{CONCLUSION AND RECOMMENDATION}

The paper aimed to establish whether the industrial attachment programme offered by three automobile institutes to their faculty was helpful in their professional development. The questionnaires were used to determine the fulfilment of the program objectives, adequacy of knowledge and skills gained, the usefulness of the program, challenges faced by the faculties and the strategies for improvement. The study also attempted to establish the general feelings of faculties about the attachment and also the researcher sought to get more insight into the attachment by getting feedback through recommendations from respondents which was also the part of the questionnaire.

The industrial attachment was viewed as an important strategy to expose faculties to real work life and to equip them with the necessary skills so that they would not only lead to being a better TVET trainer, but also who can ensure a quality TVET in Bhutan. Based on the findings of the study it can be concluded that TTIs faculties were allowed to relate theory into practice to prepare their student trainees for success in further education and the workplace. Studies on industrial attachment in a Bhutanese TVET setting were not much reported. The present study thus adds a different dimension to the literature on work-integrated learning.

From the findings of the study, it could be concluded that the faculties of the three automobile institutes expressed high satisfaction on the attainment of program objectives and the usefulness of the program. The attained objectives include acquisition of new manipulative practical skills, nurtures linkages with industry, getting students acquainted with technologies new to them and develop a positive attitude towards work. The program's usefulness lies in the opportunity to apply theory learnt into practices, opportunity to interact and share experiences and problems with industry staff and obtain mew learning experience of the trade and beyond.

The study also concluded that the industrial attachment program (IAP) for faculty had expressed high satisfaction on the adequacy of knowledge and skills during the program. However, the mean rating for the duration of attachment was the lowest with 2.93 although slightly above the resultant mean indicating the duration is too short to get the required skills. The responses in the open-ended question to provide suggestion also had comments on the extension of duration program from three to four weeks. 
The IAP had been seen to have some challenges experienced by faculties despite the above advantages and these had to be addressed for its successful implementation. For effective and efficient management of the IAP, strategies for improving the programme were also highlighted where the governing agencies have to come up with clear policies, trained mentors and assessors, monitoring and evaluation systems, timing and time frame for the IAP. The study, therefore, recommends the following:

1. Need to develop a HRD master plan for trainer's professional development by the governing agency.

2. The follow-up (supervision) must be done early so that supervisors can make suggestions to the management early.

3. Increased duration of attachment program to four weeks

4. Strengthen industry - institution linkages with the training of mentor by the host organization

5. Send faculty to relevant industries especially to the dealers for the attachment programme.

6. Ministry to provide adequate budget for the successful implementation of the prgramme.

7. With TVET gaining momentum in the terms of employment and linkage creation, such programmes may need further up-gradation.

However, further studies on the role of industries have to be done for stronger linkages and wholesome training and meaningful assessment.

\section{REFERENCES}

[1] Aleisa, A.M., \& Alabdulahfez, M.A. (2002). Cooperative education at Riyadh College of Technology: Successes and challenges. Asia-Pacific Journal of Cooperative Education, $3(2), 1-7$.

[2] Arikewuyo, M.O. (1999). Improving teachers' productivity in Nigeria, basics of education. Lagos: Triump Books Publishers.

[3] Baechle, T. R., \& Earle, R. W. (2008). Essentials of strength training and conditioning. European Journal of Innovation Management, 6(1), 41-52.

[4] Bailey, T., \& Merritt, D. (1997, February). School-to-work for the college bound. Berkeley, CA: National Center for Research in Vocational Education, University of California at Berkeley. Retrieved September 1, 2008, from http://ncrve.berkeley.edu/AllInOne/MDS-799.html

[5] Cort, P., Härkönen, A., \& Volmari, K. (2004). Professionalization of VET teachers for the future. Luxemburg: CEDEFOP.
[6] Cohen, L., \& Manion, L. (1995). Research Methods in Education (4th ed.). London: Routledge.

[7] Cullen, M. (2005). Environmental science cooperative education: Benefits for the student, the host organization, and the study program. Asia-Pacific Journal of Cooperative Education, 1(2), 1-12.

[8] Cronbach, Lee J. (1951). Coefficient alpha and the internal structure of tests. Psychometrika. Springer Science and Business Media LLC. 16 (3): 297-334.

[9] Department of Employment and Human Resource, (2016). Labour Force Survey Report, Ministry of Labour and Human Resources, Thimphu.

[10] Dodge, R. B., \& McKeough, M. (2003). Internship and the Nova Scotia Government experience case study. Education+ Training, 45(1), 45-55.Available at: https://doi.org/10.1108/00400910310459662.

[11] Donkor, F., Nsoh, S. N., \& Mitchual, S. (2009). Organizational issues and challenges of supervised industrial attachment programme in Ghana. Asia Journal of Cooperative Education, 10(1), 39-56.

[12] Finch, C.R., \& Crunkilton, J.R. (1999). Curriculum development in vocational and technical education: Planning, content, and implementation (5th ed.). Boston: Allyn \& Bacon.

[13] Furco, A. (1996). Service learning and school-to-work. Journal of Cooperative Education, 32(1), 7-14.

[14] Krejcie, R.V., \& Morgan, D.W. (1970). Determining Sample Size for Research Activities. Educational and Psychological Measurement.

[15] Matamande, W., Taderera, E., Nyikahadzoyi, L., \& Mandimika, E. (2012). An investigation of the effectiveness of work related learning: A case study of the industrial attachment programme offered by the faculty of commerce, University of Zimbabwe. Retrieved from http://www.aabri.com/manuscripts/131524.pdf. [Accessed 28 March 2018].

[16] Meyer, L. H. (2008). Tertiary assessment and higher education student outcomes: Policy, practice and research. Wellington, New Zealand: Victoria University of Wellington.

[17] MoLHR, 2016. TVET Blueprint 2016-2026: A Strategic Approach to Skilling Bhutan, DHR, Thimphu.

[18] MoLHR, 2020. TVET Statistics of Bhutan: In the quest for transforming TVET through Data-Informed Approach, Department of Technical Education; Thimphu.

[19] MoLHR, 2020. TVET Graduate Study Bhutan: Multi-Cohort online tracer study Report of TTI and IZC Graduates (20132019. Department of Technical Education; Thimphu.

[20] Olugbenga, A. F. (2009). Towards effective SIWES curriculum development in applied sciences for adequate skills utilization: A Case study of the school of applied science, Nuhu Bamali Polytechnic, Zaria' Pacific Journal of Science and Technology, 10(1), 234-239.

[21] Osuala, E.C. (1993). Introduction to Research Methodology. Onitsha: Africana-Fep Publishers. 
[22] Patton, M, (1990). Problem in Social studies in Instruction in Thai High Schools. Social Studies, 57, 61-64.

[23] Ryan, R.D., \& Imel, S. (1996). School-to-work transition: Genuine reform or the latest fad. Educational Resources Information, 4, 2-11.

[24] An investigation of the effectiveness of work related learning: A case of the industrial attachment program offered by the faculty of commerce, University of Zimbabwe; Wilson Matamande, University of Zimbabwe; Loveness Nyikahadzoi, University of Zimbabwe; Ever Taderera, Midlands State University; Elinah Mandimika, University of Zimbabwe

[25] ffah, Bernard \& Boampong, Ernest \& Adu, George \& Anokye, Rogerson \& Nti Asamoah, Jack. (2014). Issues of the Industrial Training Programme of Polytechnics in Ghana: The Case of Kumasi Polytechnic. Journal of Education and Practice. 5. 3946. 